\title{
Novel lichen-dominated hypolithic communities in the Namib Desert
}

\author{
Asunción de los Ríos ${ }^{1}$ [ Isaac Garrido-Benavent ${ }^{1,2} \cdot$ Alicia Limón $^{1} \cdot$ Errol D. Cason $^{3} \cdot$ Gillian Maggs-Kölling $^{4}$. \\ Don Cowan $^{5} \cdot$ Angel Valverde $^{6}$
}

Received: 31 March 2021 / Accepted: 29 June 2021 / Published online: 27 July 2021

(c) The Author(s) 2021

\begin{abstract}
The ventral surfaces of translucent rocks from hot desert pavements often harbor hypolithic microbial communities, which are mostly dominated by cyanobacteria. The Namib Desert fog belt supports extensive hypolithic colonization of quartz rocks, which are also colonized by lichens on their dorsal surfaces. Here, we aim to evaluate whether lichens colonize the ventral surface of the rocks (i.e., show hypolithic lifestyle) and compare the bacterial composition of these coastal hypolithic communities with those found inland. Fungal DNA barcoding and fungal and bacterial Illumina metabarcoding were combined with electron microscopy to characterize the composition and spatial structure of hypolithic communities from two (coastal and inland) areas in the Namib Desert. We report, for the first time, the structure and composition of lichendominated hypolithic communities found in the coastal zone of the Namib Desert with extensive epilithic lichen cover. Lichen modified areoles with inverted morphology of the genus Stellarangia (three lineages) and Buellia (two lineages) were the main components of these hypolithic communities. Some of these lineages were also found in epilithic habitats. These lichen-dominated hypolithic communities differed in structural organization and bacterial community composition from those found in inland areas. The hypolithic lichen colonization characterized here seems not to be an extension of epilithic or biological soil crust lichen growths but the result of specific sublithic microenvironmental conditions. Moisture derived from fog and dew could be the main driver of this unique colonization.
\end{abstract}

Keywords Cyanobacteria $\cdot$ Lichens $\cdot$ Lithobionts $\cdot$ Habitat specificity $\cdot$ Dew $\cdot$ Fog $\cdot$ Stellarangia $\cdot$ Buellia

Asunción de los Ríos

arios@mncn.csic.es

1 Biogeochemistry and Microbial Ecology Department, Museo Nacional de Ciencias Naturales, CSIC, Serrano 115 dpdo, 28006 Madrid, Spain

2 Departament de Botànica i Geologia, Facultat de Ciències Biològiques, Universitat de València (UV), C. Doctor Moliner 50, 46100 Burjassot, València, Spain

3 Department of Animal Science, University of the Free State, Bloemfontein, South Africa

4 Gobabeb-Namib Research Institute, Walvis Bay, Namibia

5 Centre for Microbial Ecology and Genomics, Department of Biochemistry, Genetics and Microbiology, University of Pretoria, Pretoria 0002, South Africa

6 Instituto de Recursos Naturales y Agrobiología de Salamanca (IRNASA-CSIC), C/ Cordel de Merinas 40-52, 37008 Salamanca, Spain

\section{Introduction}

Life in desert soil is principally constrained by water availability. Open desert soils are relatively depauperate habitats that support low-biomass microbial communities [1]. In contrast, the ventral surfaces of translucent rocks (mainly quartz or marble) often harbor hypolithic communities that constitute substantial standing biomass [2-4]. Indeed, hypolithic microbial communities are considered hotspots of primary productivity and organic matter accumulation in hyperarid deserts [5]. Under these translucent rocks, microbial communities exist in microrefugia with less stringent environmental conditions than open soils, where the overlying lithic substrate provides protection against high incident UV fluxes, generates thermal buffering, and enhances moisture availability [6].

The most common hypolithic communities in hot deserts are those dominated by cyanobacteria $[2,4,6,7]$. Mossdominated hypolithic communities have also been reported in the Mojave Desert [8] and in the cold Antarctic Dry 
Valleys $[3,9,10]$. In contrast, fungal-dominated hypolith communities have only been reported in the Antarctic Dry Valleys [9], although different fungal taxa have been detected in cyanobacteria and moss-dominated lithobiontic communities from different deserts [11-13]. These types of hypoliths may reflect different successional stages [9].

Lichenized fungi are conspicuous in both hot and cold deserts as components of soil crusts [14] or saxicolous (epilithic) communities [15-17]. As poikilohydric organisms, lichens show physiological and anatomical adaptations that allow them to survive on desert soils and rock surfaces, such as thick cortical layers, the production of photoprotective pigments, LEA-like proteins, and the development of potent antioxidant mechanisms [18]. Lichens have also frequently been reported to colonize hidden and protected endolithic microhabitats in desert ecosystems [16, 17, 19]. In contrast, the presence of lichens in hypolithic habitats has, until now, been underexplored. Previously, the colonization of the ventral surfaces of quartz rocks by the cyanolichen Peltula inversa has been described in the Namib Desert [20], and chlorolichens (i.e., lichens with eukaryotic green microalgae as photobionts) have also been found underneath small translucent flints in dew-dominated desert areas such as the highlands of Central Asia [21].

In coastal deserts, the occurrence of fog and dew, together with the existence of stable gravel plains, facilitates the development of lichens in areas where rainfall is insufficient to support extensive vascular plant growth [22, 23]. Indeed, the Namib Desert fog belt supports the world's most extensive lichen cover and a very high diversity of lichens [24]. This extensive lichen colonization gives rise to the unique and renowned "lichen fields" [25], defined by Jürgens and Niebel-Lohmann [26] as "plant formations of considerable surface area, in which epilithic to epipsammic (terricolous) lichens play the dominant role with respect to structure, cover and biomass, if compared with ferns and seed plants." Quartz rocks embedded in coastal desert pavements in the Namib Desert are frequently colonized by epilithic lichens [27].

In considering whether the communities present on the dorsal surfaces of coastal quartz rocks extended to the ventral surfaces, we investigated hypolithic microbial (fungal and bacterial) colonization using a combination of electron microscopy and rRNA gene sequencing. We also compared the hypolithic microbial communities of these coastal (fog-dominated) rocks with those found in inland (rainfalldominated) zones to evaluate their uniqueness. Water relations in the inland areas in the Namib Desert are characterized by occasional rainfall events rather than frequent fog events [28], and their hypolithic microbial communities are dominated by cyanobacteria $[4,29]$. We hypothesized that translucent rocks in these two areas, subjected to contrasting abiotic conditions and biotic structures, would support different hypolithic communities in terms of composition and predicted functions.

\section{Materials and methods}

\section{Sample collection}

Twenty-five quartz rocks showing visible hypolithic growth were collected on 15-16 April 2015 from an area (S23 ${ }^{\circ}$ $\left.3^{\prime} 23^{\prime \prime}, \mathrm{E} 14^{\circ} 38^{\prime} 42^{\prime \prime}\right)$ near the coast of the Namib Desert (105 $\mathrm{m}$ asl). This area corresponded to lichen field I [25], which is characterized by a dominance of crustose lichens on quartz gravel with a lichen density below $20 \%$ and by frequent fog events (Supplementary Fig. 1). Rocks (in the size range of 4-6-cm wide, $4-5-\mathrm{cm}$ long, and 1-2-cm high) were randomly collected, at a minimum distance of $1 \mathrm{~m}$ from each other, within a 5-m radius site and stored in sterile Whirl-Pak bags. Ten rocks were used for targeted morphological and molecular identification of lichenized fungi, five for electron microscopy analysis, and ten rocks for community structure comparison with ten rocks found inland by high-throughput sequencing. Five additional rock samples exhibiting hypolithic growth from the inland area (S23 ${ }^{\circ} 33^{\prime} 32^{\prime \prime}$, E15 $\left.{ }^{\circ} 02^{\prime} 15^{\prime \prime}\right)$, near the Gobabeb Research and Training Station (409 $\mathrm{m}$ asl), were collected for comparative microscopy studies (Supplementary Fig. 1). In total, 40 rocks were collected ( 25 near the coast and 15 inland).

\section{Identification of lichenized fungi}

Preliminary selection and identification of lichenized fungi was done visually based on the seminal work by [24] on the lichen flora of the Namib Desert. Confirmation of the identity of taxa at the genus level was done microscopically using hand-cut sections of ascomata mounted in water that were observed using a Zeiss Axioplan 2 microscope fitted with "Nomarski" differential interference contrast (DIC). This was especially important for determining the identity of crustose species belonging to the complex genus Buellia De Not. Specimens were deposited in the Royal Botanical Garden of Madrid (MA).

DNA isolation from these selected epilithic and hypolithic lichen growths was performed as follows. Lichen areoles (Buellia spp. and Stellarangia spp.), lobes (Xanthoparmelia spp.), or hypolithic growths (species not identifiable morphologically) were first ground in liquid nitrogen with a mortar and pestle. Total DNA was then extracted using the Speedtools Tissue DNA kit (Biotools® B\&M Labs., S.A), following the manufacturer's recommendations. The fungal DNA barcode nuclear ribosomal Internal Transcribed Spacer, which includes the subregions ITS1, 5.8S, and ITS2, was amplified from each sample. Three markers were also 
sequenced for Stellarangia spp. samples: the nuclear large subunit ribosomal RNA (LSU), the mitochondrial small subunit ribosomal RNA (mtSSU), and the RNA polymerase II largest subunit $(R P B 1)$. The primers used are shown in Supplementary Table 1. PCR amplifications were carried out using the Illustra Ready-To-Go GenomiPhi V3 DNA amplification kit (GE Healthcare Bio-Sciences, Pittsburgh, Pennsylvania, USA) following the manufacturer's instructions. PCR conditions for ITS amplifications were as follows: an initial 4 min heating step at $94{ }^{\circ} \mathrm{C}$, followed by 30 cycles of $1.15 \mathrm{~min}$ at $94{ }^{\circ} \mathrm{C}, 1.30 \mathrm{~min}$ at $52^{\circ} \mathrm{C}$, and $1.45 \mathrm{~min}$ at $72{ }^{\circ} \mathrm{C}$, followed by a final extension step of $10 \mathrm{~min}$ at $72{ }^{\circ} \mathrm{C}$, after which the samples were kept at $4{ }^{\circ} \mathrm{C}$. Negative controls lacking DNA were run to check for contamination. Amplicons were purified and cleaned using the QIAGEN quick spin columns (Qiagen $®)$. Both complementary DNA strands were sequenced at MACROGEN. Raw electropherograms were manually checked, trimmed, and assembled using SeqmanII v. $5.07^{\odot}$ (Dnastar Inc.). GenBank accession numbers are in the Supplementary information (Table S1).

Species identification was first approximated by comparing the ITS sequences with nucleotide data deposited in the GenBank database (http://www.ncbi.nlm.nih.gov/) using the BLAST online tool. Secondly, highly similar ITS sequences of Buellia spp. and Stellarangia spp. were retrieved and aligned independently with the software MAFFT v.7.308 [30]. Ambiguously aligned regions in the Buellia spp. dataset were automatically removed using the least stringent parameter options with GBlocks v.0.91b [31]. In Stellarangia spp., alignments of LSU, mtSSU and RPBI sequences were identically built and concatenated to the ITS sequence dataset. Phylogenetic analyses were conducted under a maximum likelihood (ML) and Bayesian inference (BI) scenarios. The online version of RAxML-HPC2 hosted at the CIPRES Science Gateway [32, 33] was chosen to infer ML phylogenies, and 1000 bootstrap pseudoreplicates were calculated to evaluate nodal support. The MrBayes analyses were conducted with two parallel, simultaneous fourchain runs executed over $1 \times 10^{8}$ generations starting with a random tree, and sampling after every $1 \times 10^{4}$ steps. The first $25 \%$ of data were discarded as burn-in, and the $50 \%$ majority-rule consensus tree and corresponding posterior probabilities were calculated from the remaining trees. Optimal substitution models for the two partitions within the nrITS (ITS1 + 2, 5.8S; Buellia spp. dataset) and five partitions (ITS1 + 2, 5.8S, LSU, mtSSU, RPB 1; Stellarangia spp. dataset) used in the above analyses (Supplementary Table 2) were inferred with PartitionFinder v.1.1.1 considering a model with linked branch lengths and the Bayesian information criterion (BIC). Average standard deviation of split frequencies (ASDSF) values below 0.005 and potential scale reduction factor (PSRF) values approaching 1.00 were considered indicators of chain convergence in the Bayesian analyses. As for tree nodal support, nodes showing Bootstrap support (BS) values equal or higher than 70\% (RAxML analyses) and Bayesian posterior probabilities (PP) equal or higher than 0.95 (MrBayes analyses) were regarded as significantly supported. Phylogenetic trees were visualized in FigTree v.1.4 (available at http://tree.bio.ed.ac.uk/softw are/tracer/), and Adobe Illustrator CS5 was used for artwork.

\section{High-throughput sequencing of hypolithic communities}

Genomic DNA was extracted from hypolithic microbial biomass scraped from quartz rocks using the PowerSoil ${ }^{\circledR}$ DNA Isolation Kit (MO BIO laboratories, Carlsbad, CA, United States). DNA quality and concentration were measured using a NanoDrop ND 1000 spectrophotometer (Thermo Fisher Scientific ${ }^{\mathrm{TM}}$ ). For bacterial DNA amplification, we followed the bacterial 16S rRNA Illumina Amplicon Protocol recommended by the Earth Microbiome Project (available at http://www.earthmicrobiome.org/protocolsand-standards/16s/), using the primer pair 515F (5'-GTG YCAGCMGCCGCGGTAA-3') and 806R (5'-GGACTA CNVGGGTWTCTAAT-3'), which amplifies the V4 region of the $16 \mathrm{~S}$ ribosomal RNA gene [34]. Fungal library preparation was performed with a two-step PCR method, using the ITS1F-KYO1 and ITS2-KYO2 primer set that spans the ITS1 region. To this end, PCR amplifications for each sample were conducted in triplicate, quantified using Quant-iT ${ }^{\mathrm{TM}}$ PicoGreen ${ }^{\circledR}$ dsDNA Assay Kit (Invitrogen) and pooled at equimolar amounts. A no-template sample was included during library preparation as a control for extraneous nucleic acid contamination. Amplicon products containing samplespecific barcodes were quantified using the Illumina library Quantification Kit ABI Prism ${ }^{\circledR}$ (Kapa Biosystems), pooled together in equal concentrations (240 ng of DNA per sample), and then cleaned using the QIA quick PCR purification kit (QIAGEN). Subsequently, the DNA pool was diluted to a final concentration of $4 \mathrm{nM}$ and then denatured and diluted to a final concentration of $4 \mathrm{pM}$ in $15 \%$ PhiX. Finally, the DNA library was loaded in MiSeq Illumina and run using the version 2 module, $2 \times 250$ pair-end, following the manufacturer's instructions. Raw reads were demultiplexed, and barcode sequences were removed by the sequencing centre. Both amplicon libraries were generated at the ASU Genomics Core (Arizona State University, USA).

\section{Amplicon quality processing, clustering, and classification}

High-throughput sequence analysis and bioinformatic processing was performed according to [35]. Briefly, 16S rRNA and ITS sequence datasets were pre-processed and trimmed using PrinSeq-lite v0.20.4 to obtain an 
average quality score $\geq 25$ using a $7 \mathrm{nt}$ window with a $4 \mathrm{nt}$ step. All sequences shorter than $100 \mathrm{bp}$ were filtered out. Paired end reads were merged using PEAR 0.9.6 [36]. Quality filtered reads were analyzed using QIIME v1.9.1 [34]. Chimeric sequences were identified and removed using Usearch v6.1.544 against the RDP "Gold" database [37] for bacteria/archaea and the UNITE database for fungi [38]. Operational taxonomic unit (OTU) picking were carried out at $99 \%$ sequence identity against the SILVA 132 database [39] for the bacterial/archaeal 16S rRNA and the UNITE v 8.2 [38] for the fungal ITS data.

The newly obtained raw high-throughput sequencing data, for both fungi and bacteria, was deposited into the
NCBI Sequence Read Archive (SRA) database (BioProject ID: PRJNA734915).

\section{Comparing coastal and inland hypolithic bacterial communities}

To compare the bacterial communities from coastal hypoliths with those from inland sites, we used 16S rRNA gene high-throughput sequencing data obtained above and from a previous study [40]. For OTU comparisons, given that the sequencing data from [40] was obtained with primers 27F/519R on a Roche 454 FLX titanium instrument, we used the OTUs closed-reference picking protocol
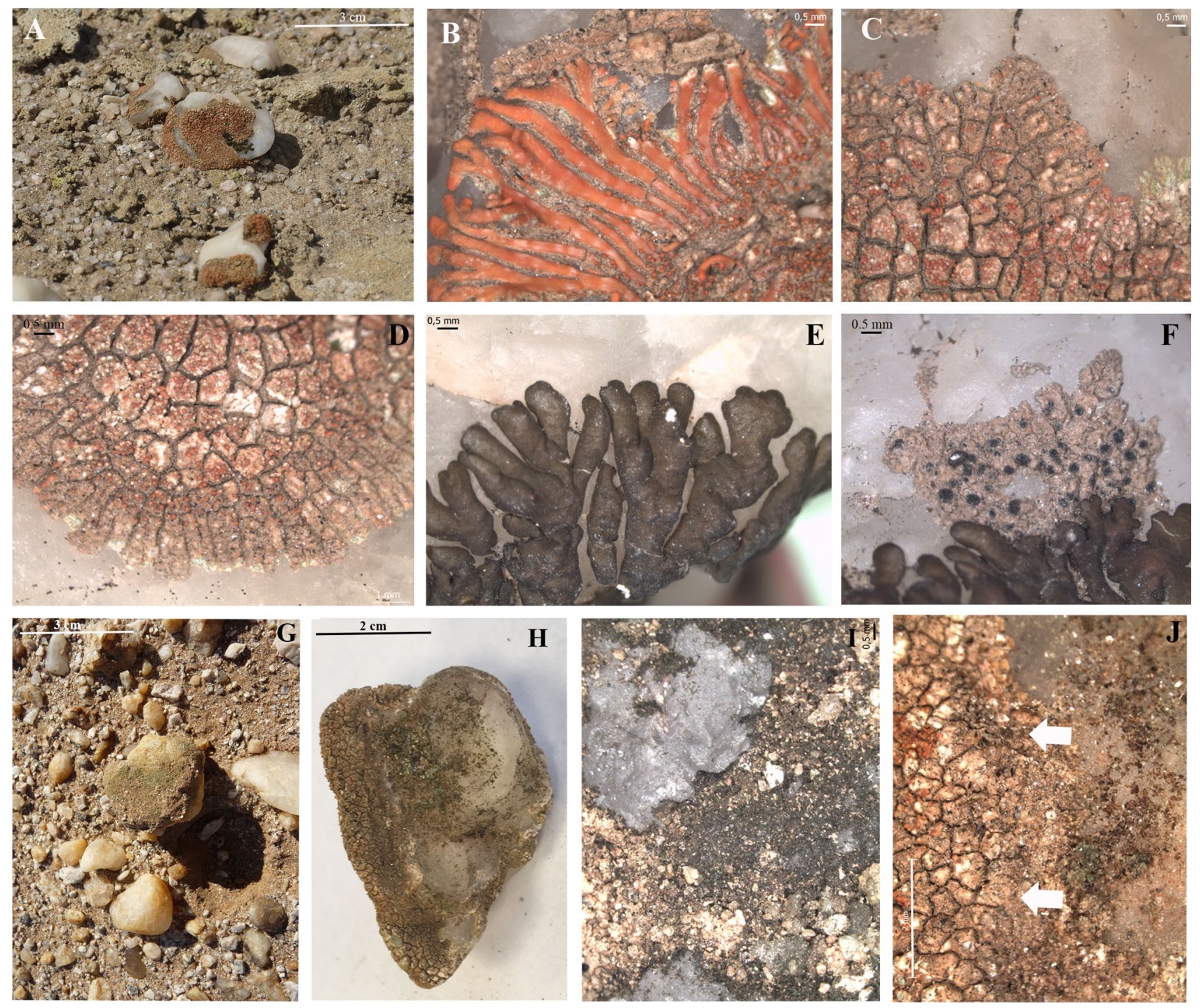

Fig. 1 A Quartz pavement in the coastal area of the Namib Desert supporting epilithic lichen colonization; B epilithic Stellarangia namibensis; $\mathbf{C}$ epilithic $S$. testudinea; D epilithic Stellarangia sp.; $\mathbf{E}$ epilithic Xanthoparmelia sp.; F epilithic Buellia sp.; G quartz rock

supporting green hypolithic community from the inland area; $\mathbf{H}$ quartz rock supporting green hypolithic community from the coastal area; I black hypolithic growth from the inland area; $\mathbf{J}$ hypolithic Stellarangia sp. areoles (arrows) from the coastal area 
implemented in QIIME v1.9.0 [34]. The OTUs closed-reference protocol allows comparison of sequences obtained using primers that targeted different regions of the $16 \mathrm{~S}$ rRNA gene and different sequence platforms [41]. Functional prediction based on OTU representative sequences was performed using PICRUSt2 version 2.1.4_b [42].

\section{Statistical analyses}

Differences in alpha diversity (Inverse Simpson, Shannon and observed number of OTUs) and relative abundance (at phylum and family levels) between coastal and inland bacterial hypolithic communities were assessed using Kruskal-Wallis tests. Differences in bacterial community composition and predicted functions between coastal and non-coastal hypolithic communities were based on Bray-Curtis dissimilarities using permutational multivariate ANOVA (PERMANOVA) [43], implemented using the adonis function in the R package vegan [44]. Withingroup variance in community composition and predicted function was performed using the betadisper function in vegan. Changes in gene abundance between coastal and non-coastal hypolithic bacterial communities were tested using Welch's t-tests implemented in STAMP [45].

\section{Characterization of hypolithic communities by scanning electron microscopy with backscattered electron imaging (SEM-BSE)}

The rock-microorganism interface was observed by scanning electron microscopy with backscattered electron imaging (SEM-BSE) [46]. Briefly, rock fragments containing hypolithic communities were fixed in glutaraldehyde $(3 \% \mathrm{v} / \mathrm{v})$ and osmium tetroxide solutions $(1 \% \mathrm{w} / \mathrm{v})$, dehydrated in a graded ethanol series (from 30 to $100 \% \mathrm{v} / \mathrm{v}$ ), and embedded in LR-White resin. The resulting blocks were finely polished, carbon coated, and observed using a FEI INSPECT 105 SEM microscope. Microprobe analyses was performed using an Oxford Instruments INCA X-act Energy Dispersive Spectrometer (EDS) microanalytical system during SEM observations.
Fig. 2 Phylogram depicting the evolutionary relationships of species within the lichenized fungal genus Stellarangia based on a four loci (ITS, LSU, $\mathrm{mtSSU}$, and $R P B 1$ ) dataset obtained using Sanger sequencing. The represented topology was obtained under a Bayesian framework using MrBayes. Sequences generated from lichen thalli are labelled with "AL," whereas those obtained in the high-throughput study (ITS data) correspond with the OTUs. Data from the remaining species depicted in the tree was obtained from GenBank (see Supplementary Table 4). Posterior probabilities (PP, Bayesian analyses) and bootstrap support (BS, RAxML analyses) are represented on branches leading to nodes. Black dots denote hypolithic habitats and white dots epilithic habitats

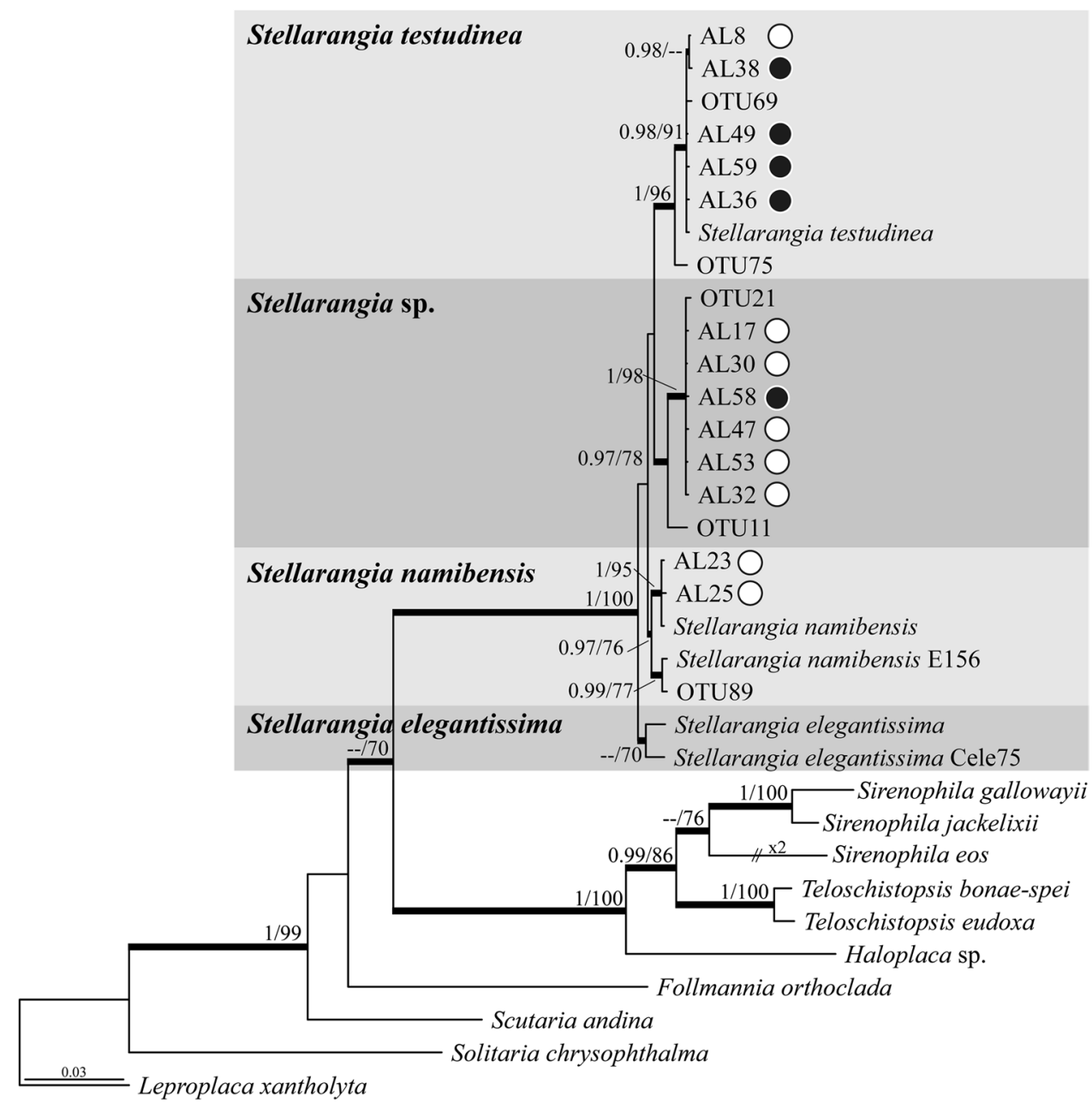




\section{Results}

\section{Visual identification of epilithic and hypolithic colonizers}

The upper surface of most quartz rocks from the coastal area was colonized by lichens (Fig. 1A). Stellarangia spp. (Fig. 1B-D) were the lichenized fungi more commonly found at epilithic locations, but species in Xanthoparmelia (Fig. 1E) and Buellia (Fig. 1F) were also observed. In contrast, the dorsal surfaces of quartz rocks from the inland area showed no lichen colonization. Hypolithic colonization was detected in quartz rocks from both localities, but two different types of communities were distinguished, cyanobacteria-dominated communities and lichen-dominated communities. Greenish (Fig. 1G-H) and black (Fig. 1I) hypolithic communities dominated by cyanobacteria were found in both, coastal and inland samples. Hypolithic communities harboring modified lichen areoles (arrows in Fig. 1J) were found only in the coastal area.
Fig. 3 Phylogram depicting the evolutionary relationships of species within the lichenized fungal genus Buellia based on Sanger sequencing of the ITS. The represented topology was obtained in the Bayesian analysis. Sequences generated from lichen thalli are labelled with "AL"; the ones within a black rectangle were obtained from epilithic thalli. Data from the remaining species depicted in the tree was obtained from GenBank (see Supplementary Table 5). Posterior probabilities (PP, Bayesian analyses) and bootstrap support (BS, RAxML analyses) are represented on branches leading to nodes. Black dots denote hypolithic habitats and white dots epilithic habitats

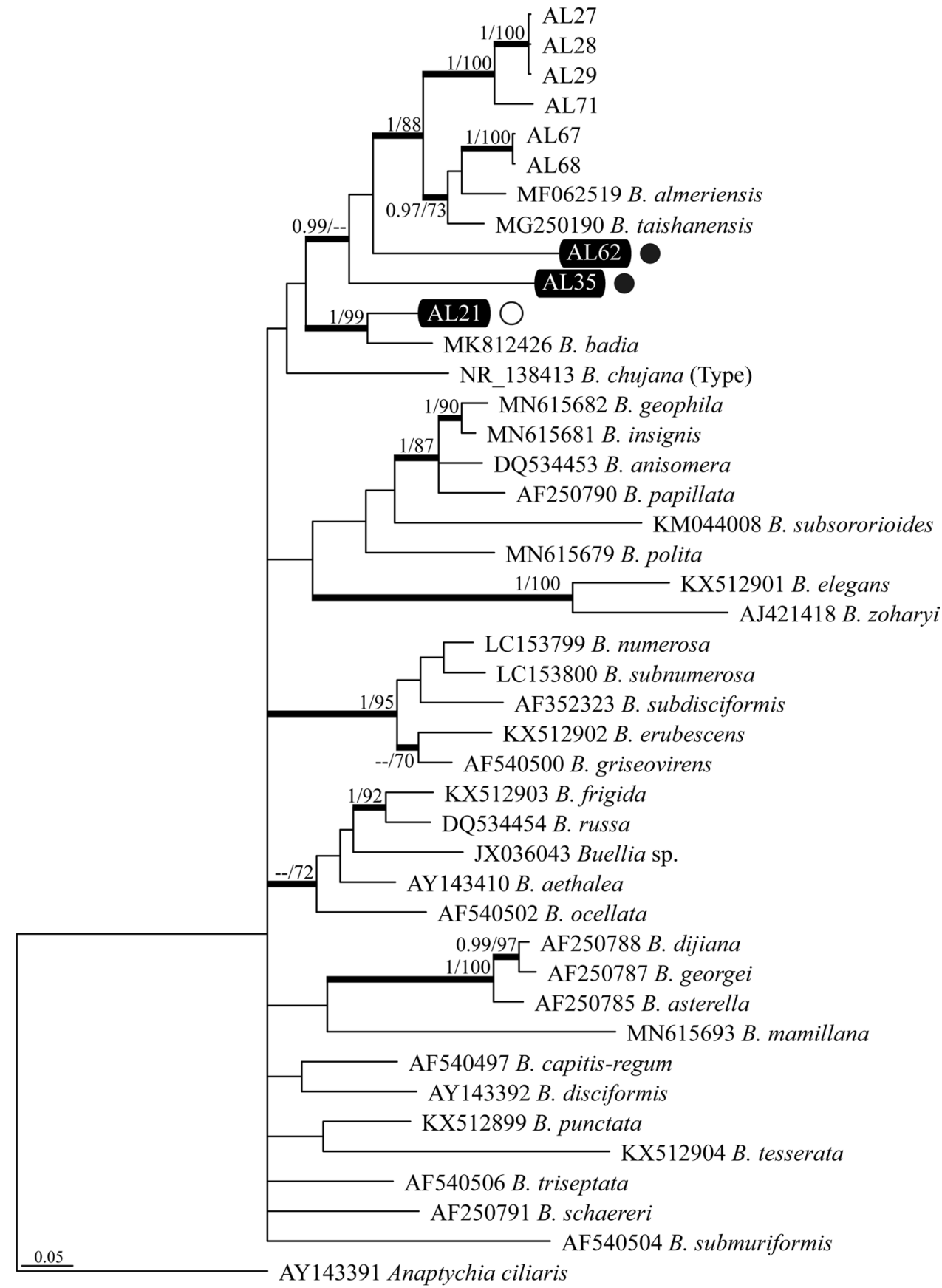




\section{Targeted molecular and phylogenetic identification of epilithic and hypolithic fungal colonizers}

Three distinct genetic lineages of Stellarangia spp. were revealed by BLAST searches of the ITS sequences obtained from epilithic lichen areoles. One such lineage represented the species Stellarangia namibensis (Kärnefelt) Frödén, Arup \& Søchting and another S. testudinea (V. Wirth \& Kärnefelt) Frödén, Arup \& Søchting (Supplementary Table 3). Our ITS sequences clustered into statistically wellsupported clades representing these two taxa in our fourloci ML and Bayesian phylogenetic reconstructions (Fig. 2). The third Stellarangia lineage formed an independent and well-supported $(\mathrm{PP}=1 ; \mathrm{BS}=98 \%)$ clade in our phylogenies. However, relationships of this lineage with clades representing the other Stellarangia species were not supported (Fig. 2). The ITS sequence generated from an epilithic thallus of a Buellia species (sample AL21) showed the closest match to B. badia (Fr.) A. Massal with a sequence similarity of $91 \%$ (Supplementary Table 3), whereas samples AL35 and AL62 were only distantly related to any other known Buellia species. In fact, the former two lineages formed a statistically well-supported clade ( $\mathrm{PP}=1 ; \mathrm{BS}=99 \%)$ in our ML and Bayesian phylogenetic trees (Fig. 3). Finally, the ITS sequences generated from Xanthoparmelia thalli had closest matches to $X$. taractica (Kremp.) Hale, although with a relatively low sequence similarity $(91.7 \%$; Supplementary Table 3).

Hypolithic lichen thalli contained species of the genus Stellarangia (three distinct lineages) and Buellia (two lineages). Hypolithic Stellarangia sequences were identical or closely matched to sequences obtained from epilithic $S$. testudinea and Stellarangia sp. (Fig. 2). In contrast, ITS sequences of hypolithic Buellia spp. were substantially dissimilar to those obtained from epilithic thalli (Supplementary Table 3) and thus were located into an unrelated phylogenetic clade, which was the sister $(\mathrm{PP}=1$; $\mathrm{BS}=88 \%$ ) to a subclade containing $B$. almeriensis Llimona and B. taishanensis Q.D. Wang \& Z.F. Jia (Fig. 3).

\section{High-throughput sequencing of fungal ITS regions from lichen-dominated hypolithic communities}

The ITS metabarcoding analysis revealed that lichen-forming fungi were present in all analyzed coastal hypolithic communities, including these from rocks without lichen epilithic colonization. These results also confirmed that these communities were mostly dominated by the lichenforming genus Stellarangia (Fig. 4A-B). Phylogenetic analyses (Fig. 2) revealed that some Stellarangia OTUs were closely related to Stellarangia sp., while others were closely related to $S$. testudinea. In contrast, samples with conspicuous blackish hypolithic growths and scarce lichen thallus development were dominated by OTUs belonging to the non-lichenized fungal genus Alternaria.

\section{Spatial organization of hypolithic communities}

Hypolithic communities from coastal and inland samples shared some spatial structural features (Fig. 5A-B). Dense aggregates with dominance of filamentous cells occupied the proximal layer (with reference to the rock), while a broader loose matrix with more dispersed cells retaining numerous soil mineral fragments occupied the distal layer (Fig. 5A-D). However, hypolithic communities from both areas differed markedly in composition (Fig. 6). In the inland samples, cellular ultrastructure and morphology revealed that filamentous cyanobacteria (Fig. 5C), accompanied by aggregates of putative coccoid cyanobacteria (black arrows in Fig. 5E), dominated the proximal dense layer in hypolithic communities. In contrast, in the coastal samples, lichen symbiont cells were the main components of this dense layer (Fig. 5B). Fungal hyphae appeared associated to green microalgae cells in this dense layer (Fig. 5D), but extended downward (towards the underlying soil) and were associated to different mineral fragments (Fig. 5B). The observed structure resembles a lichen heteromerous thallus organization, with an algal (photobiont)
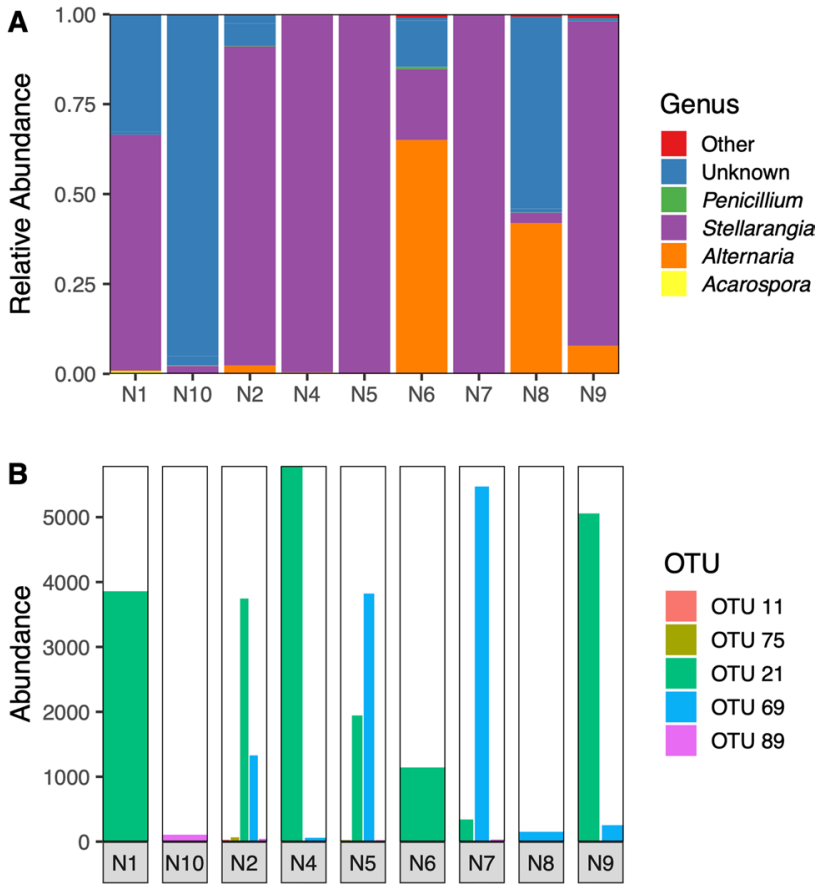

Fig. 4 A Relative abundance of fungal genera (A) and fungal OTUs (B) in hypolithic growths from coastal area (N1-N10) obtained through high-throughput Illumina sequencing. N1, N2, N4, N5, and N6 did not show visible epilithic growth, but epilithic Stellarangia thalli were observed in samples N7, N9, and N10 and Xanthoparmelia $\mathrm{sp}$. in sample $\mathrm{N} 8$ 
layer differentiated from a medullar layer composed of fungal hyphae. However, this structure lacked an upper cortex. Putative cyanobacteria were frequently observed in the proximity of hyphae from the loose layer at the soil face (black arrows in Fig. 5F). Bacteria-like cell aggregates were detected in both types of hypolithic communities and frequently found in areas dominated by cyanobacteria (white arrows in Fig. 5E-F).

\section{Anatomical features of hypolithic lichens}

A common feature of lichens found on the ventral surfaces of quartz rocks was an inverse internal morphology, with an algal layer exposed toward the quartz rock surface (Fig. 6, Fig. 7A-B) and no upper cortex (Fig. 7A). In areoles of hypolithic Stellarangia testudinea, algal cells were also observed within isidia (i.e., lichen asexual propagule) in the lichen surface exposed to the soil (black arrow in Fig. 7B). Some lichen areoles grew from the hypolithic lichen thallus toward the surface (Fig. 7C). In fact, lichens expanded from the center to the lateral margins of the rock (Fig. 7D) showing gradual changes in their anatomy (Fig. 6). Lichen areoles showed an upper cortex in the lateral margins of rocks, either very thin and orientated toward the rock in areas under the soil surface (Fig. 7E) or broad and orientated opposite to the rock surface above
Fig. 5 SEM-BSE images of hypolithic growths. A Cyanobacteria-dominated hypolithic community from the inland area. B Lichen-dominated hypolithic community from the coastal area. C Filamentous cyanobacteria closely associated to the ventral surface of quartz rock from the inland area. D Algal and fungal symbiont lichen cells in the dense layer of a hypolithic growth from the coastal area. E Filamentous cyanobacteria associated to aggregates of putative coccoid cyanobacteria (black arrows) and heterotrophic bacteria (white arrow) in the dense layer of a hypolithic growth from the inland area. F Filamentous cyanobacteria (black arrows) and aggregates of coccoid bacteria cells (white arrows) associated to fungal hyphae in the looser layer of hypolithic community from the coastal area
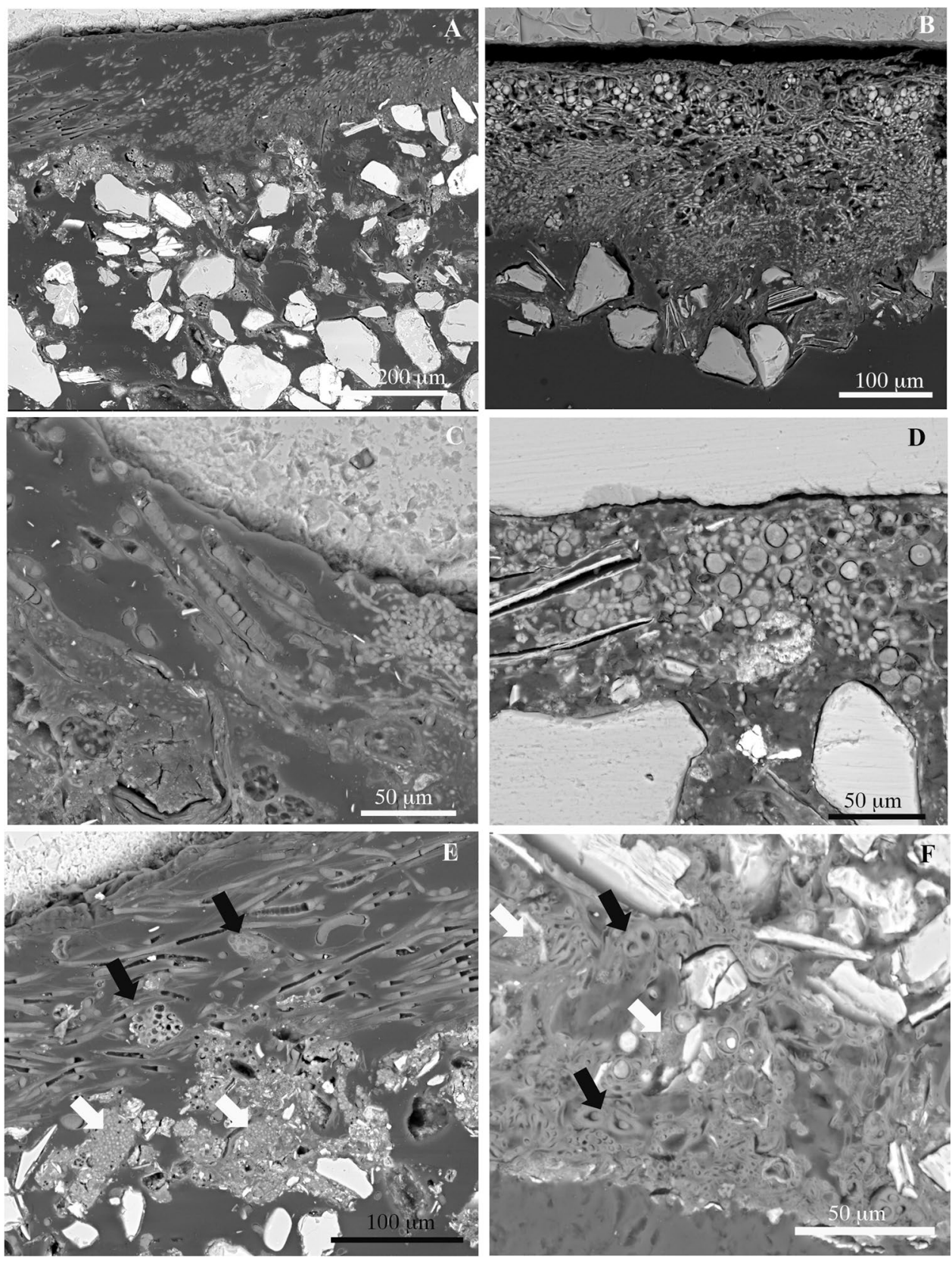
the soil surface (arrow in Fig. 7D). Aggregates of associated algal and fungal cells without a clear lichen thallus structure were also occasionally observed on the margins of the rock surfaces (Fig. 7F).

\section{Bacterial diversity and composition}

Bacterial alpha diversity values were similar between the two types of hypoliths (Supplementary Fig. 2). Overall, bacterial communities were dominated by the phyla Proteobacteria (36\% on average), Cyanobacteria (29\%), Actinobacteria (15\%), Bacteroidetes (10\%), and Thermi (5\%) (Fig. 8A). The relative abundance of Proteobacteria was significantly higher in inland hypoliths compared to coastal hypoliths (Kruskal-Wallis, $\mathrm{P}<0.05$ ), while the relative abundance of Bacteroidetes and Thermi was significantly higher in coastal hypoliths compared to non-coastal hypoliths (Kruskal-Wallis, $\mathrm{P}<0.05$ ). At the family level (Supplementary Fig. 3), Sphingomonadaceae (9\%), Phormidiaceae (9\%), Xenococcaceae (7\%), and Acaryochloridaceae (5\%) mainly contributed to the bacterial community. The relative abundance of the families Sphingomonadaceae, Acaryochloridaceae, Geodermatophilaceae, Cytophagaceae, Bradyrhizobiaceae, and Trueperaceae was significantly higher in coastal hypoliths than in inland hypoliths (Kruskal-Wallis, $\mathrm{P}<0.05$ ).

The taxonomic (OTU level) and predicted functional (KO level) community structure of hypolithic bacterial communities from coastal and inland areas differed markedly as revealed by NMDS ordinations (Fig. 8B-C) and PERMANOVA analysis $(\mathrm{P}<0.01$ in both cases). Furthermore, non-coastal hypoliths were more variable in their taxonomic and functional profiles than coastal hypoliths (permutation dispersion: $\mathrm{P}<0.01$ in both cases).

\section{Discussion}

Here, we characterize, for the first time, lichen-dominated hypolithic communities from the Namib Desert. Previous research has reported that the distribution of terricolous lichens in the Namib Desert depends on factors such as distance to the coast, elevation, climatic gradients, wind and sand force, substrate, and physiological adaptations [25, 47]. The extensive growth of epilithic and crust forming coastal lichens is thought to be supported by moisture content derived from fog and dew [22, 23, 48]. Water availability has also been considered an important determinant in shaping hypolithic microbial community structure along an inverse fog-rainfall gradient across the central Namib Desert [4]. Hence, the frequent fog and dew events in these coastal areas could also explain the establishment of lichen-dominated hypolithic communities, as the hypolithic habitat increases water retention by shading $[2,20,49]$.

Hypolithic habitats in dryland soils provide specific microclimatic conditions that facilitate a level of biocomplexity not possible in surrounding "open" soils [50]. In agreement with this observation, electron microscopy characterization revealed complex spatial structures formed by aggregates of microorganisms from different taxonomic groups trapping soil mineral components and closely associated to the quartz lithic substrate. In fogdominated coastal areas, filamentous fungi were the main structural components of these communities. Conversely, cyanobacteria were the dominant structural components in communities from inland sites. The structures of lichendominated hypolithic communities were more dense than those without lichens, presumably because hypolithic lichen symbionts provide a high degree of thallus
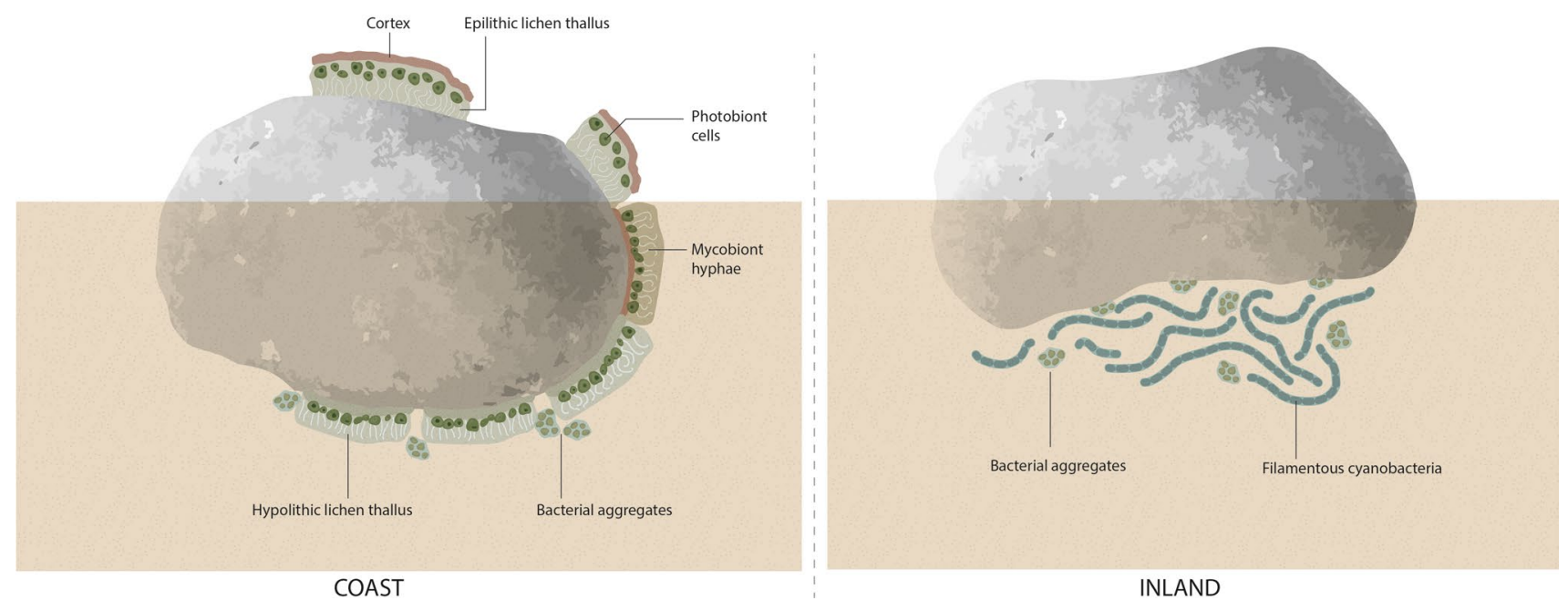

Fig. 6 Scheme of lichen-dominated (coastal area) and cyanobacteria (inland area) dominated hypolithic communities 
organization. In lichen-dominated communities, medullar hyphae were associated to bacterial aggregates and showed clear interactions with soil mineral fragments. A similar relationship was observed between filamentous cyanobacteria and soil mineral fragments in cyanobacteria-dominated communities. Hypolithic aggregates of cyanobacteria and heterotrophic bacteria are generally embedded in a dense matrix of extracellular polymeric substance (EPS), which plays key structural and functional roles [17]. The contribution of EPS to the spatial structures of hypolithic biomass found in the Namib Desert could be more relevant in inland cyanobacteria-dominated communities, because in coastal lichen-dominated communities, bacterial aggregates are restricted to marginal areas at the soil surface. EPS matrices are critically important for the retention of moisture [17], which could be essential for communities in inland (hyper-arid) areas where fog, dew, and rainfall events are very rare and atmospheric relative humidity values are significantly lower than in coastal areas. In contrast to Antarctic moss-dominated hypoliths, in which cyanobacteria frequently associates to the quartz surface between the rock and the moss [10], in the cryptogam-dominated hypolithic community described here, lichen symbionts were closely associated with the quartz rock, and cyanobacteria were not observed at the interface.
Fig. 7 SEM-BSE images of hypolithic lichens. A Lichen thalli with inverse internal morphology showing an algal layer exposed toward the quartz rock and lack of upper cortex. B Stellarangia testudinea areoles showing isidia (arrow) in the lichen surface exposed to the soil. C Lichen hypolithic growth showing at the ventral face a section with inverse internal morphology and a growth expansion orientated toward the soil surface. D Lichen areoles expanding to the lateral margins of the rocks corresponding to the rock showed in the inset, showing gradual changes in their anatomy. Arrow points to lichen areole at soil surface with upper cortex and non-inverse internal morphology. E Lichen areoles at the lateral margin of the rocks with inverse morphology and thin upper cortex. F, Associations of algal and fungal lichen symbiont cells without a clear lichen thallus structure
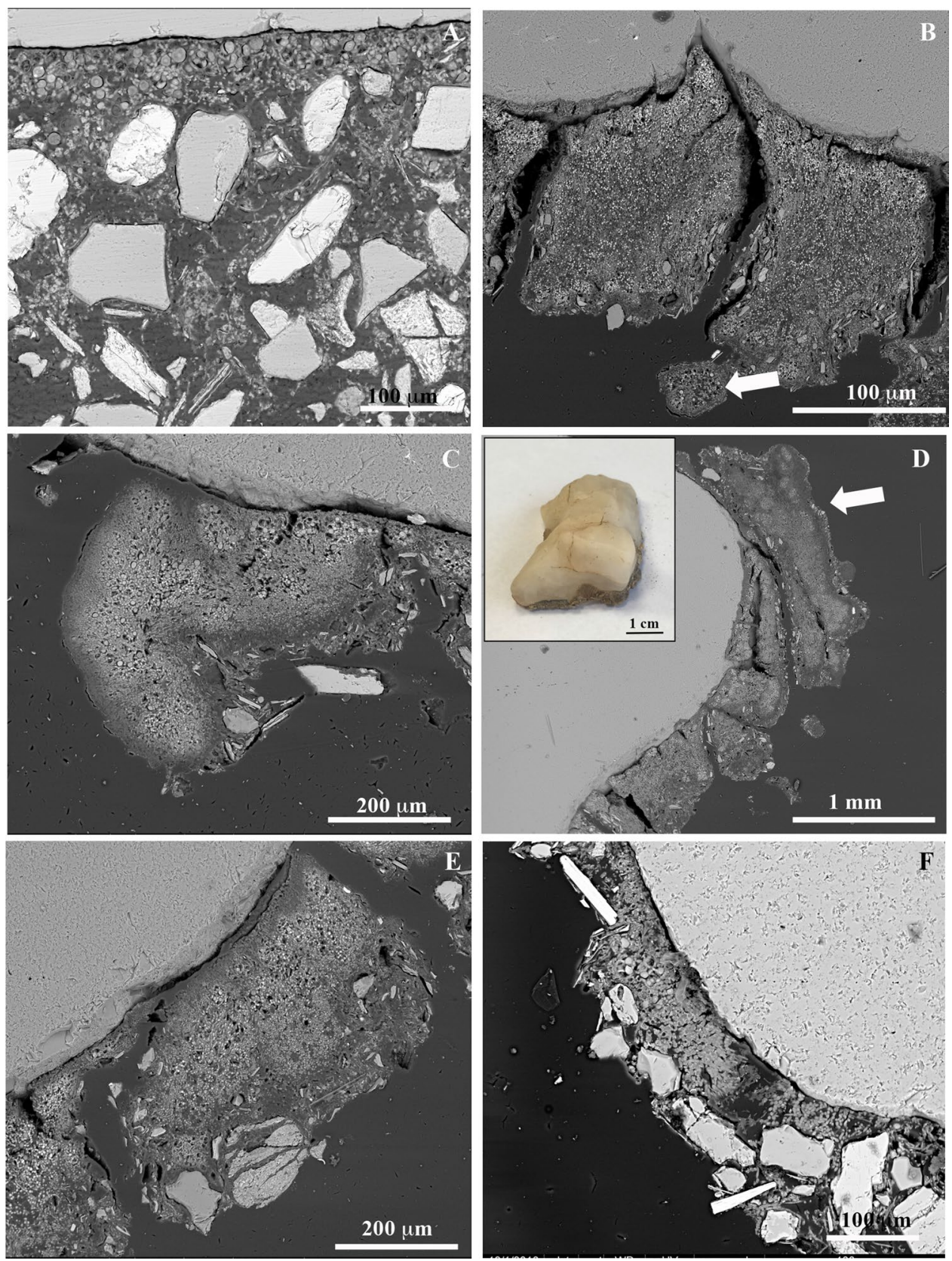

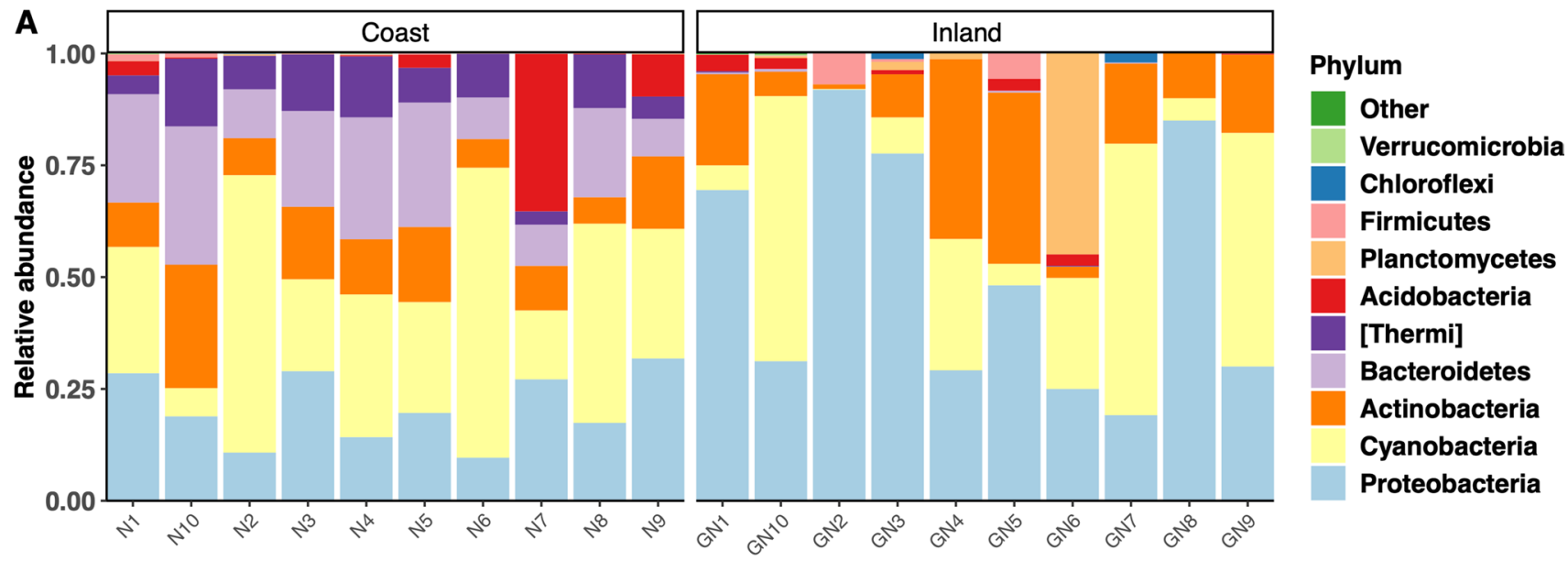

B Taxonomic composition (OTUs)

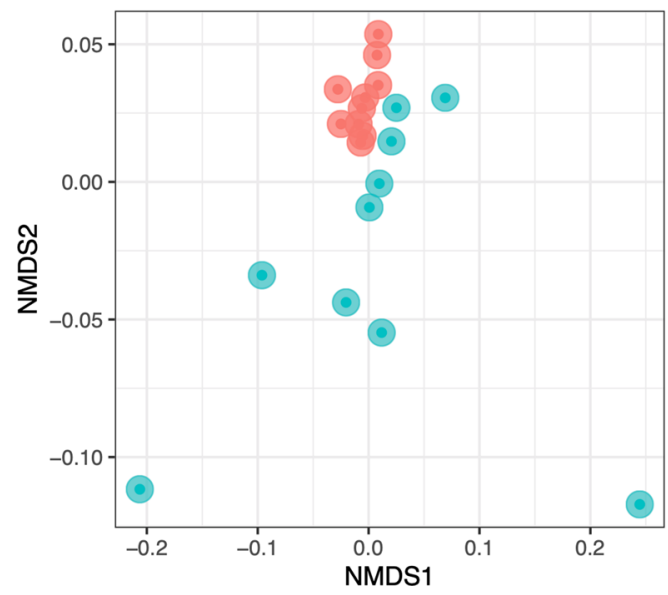

C Functional composition (KOs)

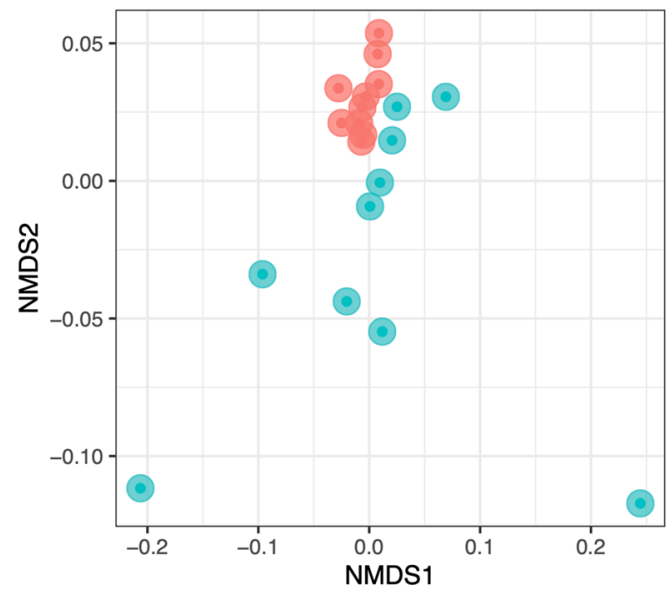

Hypoliths

(1) Coast

(-) Inland
Fig. 8 A Relative abundance of bacterial phyla in hypolithic growths from coastal (N1-N10) and inland (GN1-GN10) areas obtained through high-throughput Illumina sequencing. Non-metric multidimensional scaling (NMDS) ordination plots (Bray-Curtis dissimi- larities) from coastal (N1-N10) and inland (GN1-GN10) sampling points, showing the differences in taxonomic $(\mathbf{B})$ and functional $(\mathbf{C})$ composition
The bacterial communities found in coastal and inland hypoliths were clearly different in both taxonomy and predicted function. This is expected, as it has previously been reported that lichens harbor a specific microbiome and that different microbiomes perform different functions [51, 52]. Indeed, Bacteroidetes, which showed a higher abundance in lichen-dominated coastal hypoliths compared to cyanobacteria-dominated inland hypoliths, are common in marine and maritime lichens [52]. Bacteroidetes are typically classified as copiotrophs and therefore preferring high nutrient availability [53]. In contrast, Firmicutes, Actinobacteria, and Proteobacteria, which are also ubiquitous in lichens [51, 54], did not display any difference in relative abundance between the two types of hypoliths. Altogether, it seems that both biotic (i.e., the presence of lichens) and abiotic factors (e.g., nutrient levels, water availability) likely determine the composition and predicted functional repertories of the bacterial communities of the two types of hypoliths.
The increase in taxonomic and functional similarity in coastal hypoliths is an indication of biotic homogenization, which may indicate a more prominent role of deterministic processes (i.e., habitat filtering) in the assembly of those communities.

The rocks harboring lichen-dominated hypolithic communities were part of a lichen field with high density of saxicolous and crust-forming lichens. However, the hypolithic lichen colonization reported here seems not to be an extension of epilithic or biological soil crust lichen growths. While some rocks showed colonization by the same Stellarangia species in both epilithic and hypolithic locations, others only showed hypolithic or epilithic lichen colonization. In addition, connections between hypolithic growths and biological soil crusts as those reported for the cyanolichen Peltula inversa [20] were not observed at the studied lichen field. Hence, lichendominated hypolithic colonization seems to be the result of specific sublithic microenvironmental conditions. Indeed, 
hypolithic lichens were adapted to this microenvironment because they showed inverted morphology. The inverted morphology is thought to be an adaptive mechanism to cope with the high irradiance and low water availability that characterize desert soils [20]. Two probably new lichen-forming fungal species were reported in this study, one assigned to the genus Stellarangia and the other to the genus Buellia, which suggest that these cryptic habitats located under coastal quartz rocks could act as reservoirs of unknown fungal taxa.

Supplementary Information The online version contains supplementary material available at https://doi.org/10.1007/s00248-021-01812-w.

Acknowledgements The authors thank the technicians of the MNCNCSIC Microscopy Service and Esther Rodríguez (MNCN) for technical assistance. Also acknowledged is the technical support of the Core facilities at Arizona State University for preparing the bacterial and fungal libraries and Illumina sequencing. Thanks are also extended to the staff of the Gobabeb-Namib Research Institute for their logistic support.

Funding Open Access funding provided thanks to the CRUE-CSIC agreement with Springer Nature. DC acknowledges the financial support of the University of Pretoria and the National Research Foundation of South Africa. AV was supported by the project "CLU-2019-05 IRNASA/CSIC Unit of Excellence," funded by the Junta de Castilla y León and co-financed by the European Union (ERDF "Europe drives our growth"). This work was supported by grants CTM2015-64728-C22-R (MINECO/FEDER, EU) and PID2019-105469RB-C22 (MICINN).

Open Access This article is licensed under a Creative Commons Attribution 4.0 International License, which permits use, sharing, adaptation, distribution and reproduction in any medium or format, as long as you give appropriate credit to the original author(s) and the source, provide a link to the Creative Commons licence, and indicate if changes were made. The images or other third party material in this article are included in the article's Creative Commons licence, unless indicated otherwise in a credit line to the material. If material is not included in the article's Creative Commons licence and your intended use is not permitted by statutory regulation or exceeds the permitted use, you will need to obtain permission directly from the copyright holder. To view a copy of this licence, visit http://creativecommons.org/licenses/by/4.0/.

\section{References}

1. Makhalanyane TP, Valverde A, Gunnigle E, Frossard A, Ramon JB, Cowan DA (2015) Microbial ecology of hot desert edaphic systems. FEMS Microbiol Rev 39:203-221. https://doi.org/10. 1093/femsre/fuu011

2. Warren-Rhodes KA, Rhodes KL, Pointing SB, Ewing SA, Lacap DC, Gómez-Silva B, Amundson R, Friedmann EI, McKay CP (2006) Hypolithic cyanobacteria, dry limit of photosynthesis, and microbial ecology in the hyperarid Atacama Desert. Microb Ecol 52:389-398. https://doi.org/10.1007/s00248-006-9055-7

3. Cowan DA, Pointing SB, Stevens MI, Cary C, Stomeo F, Tuffin IM (2011) Distribution and abiotic influences on hypolithic microbial communities in an Antarctic Dry Valley. Polar Biol 34:307-311. https://doi.org/10.1007/s00300-010-0872-2

4. Stomeo F, Valverde A, Pointing SB, McKay CP, Warren-Rhodes KA, Tuffin MI, Seely M, Cowan DA (2013) Hypolithic and soil microbial community assembly along an aridity gradient in the
Namib Desert. Extremophiles 17:329-337. https://doi.org/10. 1007/s00792-013-0519-7

5. Mergelov N, Dolgikh A, Shorkunov I, Zazovskaya E, Soina V, Yakushev A, Federov-Davydov D, Pryakhin S, Dobryansky A (2020) Hypolithic communities shape soils and organic matter reservoirs in the ice-free landscapes of East Antarctica. Sci Rep 10:10277. https://doi.org/10.1038/s41598-020-67248-3

6. Pointing SB, Warren-Rhodes KA, Lacap DC, Rhodes KL, McKay CP (2007) Hypolithic community shifts occur as a result of liquid water availability along environmental gradients in China's hot and cold hyperarid desserts. Environ Microbiol 9:414-424. https://doi.org/10.1111/j.1462-2920.2006.01153.x

7. Weber B, Wessels DJK, Deutschewitz K, Dojani S, Reichenberger H, Büdel B (2013) Ecological characterization of soil-inhabiting and hypolithic soil crusts within the Knersvlakte. South Africa Ecol proces 2:8. https://doi.org/10.1186/2192-1709-2-8

8. Ekwealor JTB, Fisher KM (2020) Life under quartz: hypolithic mosses in the Mojave Desert. PLoS One 15:e235928. https://doi. org/10.1371/journal.pone.0235928

9. Cowan DA, Khan N, Pointing SB, Cary C (2010) Diverse hypolithic refuge communities in the McMurdo Dry Valleys. Antarctic Sci 22:714-720. https://doi.org/10.1017/S0954102010000507

10. De los Ríos A, Cary C, Cowan D, (2014) The spatial structures of hypolithic communities in the dry valleys of East Antarctica. Polar Biol 37:1823-1833. https://doi.org/10.1007/s00300-014-1564-0

11. Schlesinger WH, Pippen JS, Wallenstein MD, Hofmockel KS, Klepeis DM, Mahall BE (2003) Community composition and photosynthesis by photoautotrophs under quartz stones, southern Mojave Desert. Ecology 84:3222-3231. https://doi.org/10.1890/02-0549

12. Khan N, Tuffin M, Stafford W, Cary C, Lacap DC, Pointing SB, Cowan D (2011) Hypolithic microbial communities of quartz rocks from Miers Valley, McMurdo Dry Valleys, Antarctica. Polar Biol 34:1657-1668. https://doi.org/10.1007/s00300-011-1061-7

13. Wei STS, Lacap-Bugler DC, Lau MCY, Caruso T, Rao S, de los Ríos A, Archer SK, Chiu JMY, Higgins C, Van Nostrand JD, Zhou J, Hopkins DW, Pointing SB (2016) Taxonomic and functional diversity of soil and hypolithic microbial communities in Miers Valley McMurdo Dry Valleys, Antarctica. Front Microbiol 7:1742. https://doi.org/10.3389/fmicb.2016.01642

14. Belnap J, Weber B, Büdel B (2016) Biological soil crusts as an organizing principle in drylands. Springer, Heidelberg. https://doi. org/10.1007/978-3-319-30214-0

15. Øvstedal DO, Lewis-Smith RI (2001) Lichens of Antarctica and South Georgia: a guide to their identification and ecology. Cambridge University Press, Cambridge. https://doi.org/10.14430/arctic750

16. Wierzchos J, de los Ríos A, Ascaso C (2012) Microorganisms in desert rocks: the edge of life on Earth. Int Microbiol 15:171-181. https://doi.org/10.2436/20.1501.01.170

17. De los Ríos A, Wierzchos J, Ascaso C (2014) The lithic microbial ecosystems of Antarctica's McMurdo Dry Valleys. Antarctic Sci 26:459-477. https://doi.org/10.1017/S0954102014000194

18. Armstrong RA (2017) Adaptation of lichens to extreme conditions In: Shukla V, Kumar S, Kumar N (eds) Plant Adaptation Strategies in Changing Environment. Springer, Singapore. https://doi.org/10.1007/978-981-10-6744-0_119

19. Coleine C, Stajich JE, De Los RA, Selbmann L (2021) Beyond the extremes: rocks as ultimate refuge for fungi in drylands. Mycologia 113:108-133. https://doi.org/10.1080/00275514.2020.1816761

20. Büdel B, Schultz M (2003) A way to cope with high irradiance and drought: inverted morphology of a new cyanobacterial lichen, $\mathrm{Pel}$ tula inversa sp. nova, from the Nama Karoo, Namibia. In: Jensen $\mathrm{J}$ (ed) Bibliotheca lichenologica. Lichenological Contributions in Honour of G.B. Feige. J. Cramer in der Gebr. Borntaeger Verlagbuchhandlg, Berlin, Stuttgart, pp 225-232

21. Schubert R (1982) Lichens of Central Asia. J Hattori Bot Lab 53:341-343 
22. Rundel PW (1978) Ecological relationships of desert fog zone lichens. Bryologist 81:277-293. https://doi.org/10.2307/3242189

23. Lange OL, Green TGA, Meyer A, Zellner H (2007) Water relations and carbon dioxide exchange of epiphytic lichens in the Namib fog desert. Flora 202:479-487. https://doi.org/10.1016/j.flora.2006.09.006

24. Wirth V (2010) Lichens of the Namib Desert: a guide to their identification. Klaus Hess Verlag, Göttingen. https://doi.org/10. 13158/heia.24.1.2011.167

25. Schieferstein B, Loris K (1992) Ecological investigations on lichen fields of the central Namib. Vegetatio 98:113-128. https:// doi.org/10.1007/BF00045550

26. Jürgens N, Niebel-Lohomann A (1995) Geobotanical observations on lichen fields of the Southern Namib Desert. Mitteilungen aus dem Institut für Allgemeine Botanik Hamburg 25:135-156

27. Hinchliffe G, Bollard-Breen B, Cowan DA, Doshi A, Gillman LN, Maggs-Kolling G, de los Ríos A, Pointing SB (2017) Advanced photogrammetry to assess lichen colonization in the hyper-arid Namib Desert. Front Microbiol 8:2083. https://doi.org/10.3389/fmicb.2017.02083

28. Eckardt FD, Soderberg K, Coop LJ, Muller AA, Vickery KJ, Grandin RD, Jack C, Kapalanga TS, Herschel J (2013) The nature of moisture at Gobabeb, in the central Namib Desert. J Arid Environ 93:7-19. https://doi.org/10.1016/j.jaridenv.2012.01.011

29. Van Goethem MW, Makhalanyane TP, Cowan DA, Valverde A (2017) Cyanobacteria and Alphaproteobacteria may facilitate cooperative interactions in niche communities. Front Microbiol 8:2099. https://doi.org/10.3389/fmicb.2017.02099

30. Katoh K, Standley DM (2013) MAFFT multiple sequence alignment software Version 7: improvements in performance and usability. Mol Biol Evol 30:772-780. https://doi.org/10.1093/molbev/mst010

31. Castresana $\mathbf{J}$ (2000) Selection of conserved blocks from multiple alignments for their use in phylogenetic analysis. Mol Biol Evol 17:540 552. https://doi.org/10.1093/oxfordjournals.molbev.a026334

32. Stamatakis A, Hoover P, Rougemont J (2008) A rapid bootstrap algorithm for the RAxML web servers. Systematic Biol 57:758771. https://doi.org/10.1080/10635150802429642

33. Miller MA, Pfeiffer W, Schwartz T (2010) Creating the CIPRES Science Gateway for inference of large phylogenetic tres. Gateway Computing Environments Workshop (GCE), New Orleans, LA, 2010, pp. 1-8,https://doi.org/10.1109/GCE.2010.5676129

34. Caporaso JG, Kuczynski J, Stombaugh J, Bittinger K, Bushman FD, Costello EK, Fierer N, González Peña A, Goodrich JK, Gordon JI, Huttley GA, Kelley ST, Knights D, Koenig JE, Ley RE, Lozupone CA, McDonald D, Muegge BD, Pirrung M, Reeder J, Sevinsky JR, Turnbaugh PJ, Walters WA, Widmann J, Yatsunenko T, Zaneveld J, Knight R (2010) QIIME allows analysis of highthroughput community sequencing data. Nat Methods 7:335-336. https://doi.org/10.1038/nmeth.f.303

35. Cason ED, Mahlomaholo BJ, Taole MM, Abong GO, Vermeulen JG, de Smidt O, Vermeulen M, Steyn L, Valverde A, Viljoen B (2020) Bacterial and fungal dynamics during the fermentation process of sesotho, a traditional beer of Southern Africa. Front Microbiol 11:1451. https://doi.org/10.3389/fmicb.2020.01451

36. Zhang J, Kobert K, Flouri T, Stamatakis A (2014) PEAR: A fast and accurate Illumina Paired-End reAd mergeR. Bioinform 30:614-620. https://doi.org/10.1093/bioinformatics/btt593

37. Edgar RC (2010) Search and clustering orders of magnitude faster than BLAST. Bioinform 26:2460-2461. https://doi.org/10.1093/ bioinformatics/btq461

38. Abarenkov K, Nilsson RH, Larsson K, Alexander IJ, Eberhardt U, Erland S, Høiland K, Kjøller R, Larsson E, Pennanen T, Sen R, Taylor AFS, Tedersoo L, Ursing BM, Vrålstad T, Liimatainen K, Peintner U, Kõljalg U (2010) The UNITE database for molecular identification of fungi - recent updates and future perspectives. New Phytol 186:81-285. https://doi.org/10.1111/j.1469-8137.2009.03160.x
39. Quast C, Pruesse E, Yilmaz P, Gerken J, Schweer T, Yarza P, Peplies J, Glöckner FO (2013) The SILVA ribosomal RNA gene database project: improved data processing and web-based tools. Nucleic Acids Res 41:590-596. https://doi.org/10.1093/nar/gks1219

40. Valverde A, Makhalanyane TP, Seely M, Cowan DA (2015) Cyanobacteria drive community composition and functionality in rock-soil interface communities. Mol Ecol 24:812-821. https:// doi.org/10.1111/mec.13068

41. Lozupone CA, Stombaugh J, Gonzalez A, Ackermann G, Wendel D, Vázquez-Baeza Y, Jansson JK, Gordon JI, Knight R (2013) Meta-analyses of studies of the human microbiota. Genome Res 23:1704-1714. https://doi.org/10.1101/gr.151803.112

42. Douglas GM, Maffei VJ, Zaneveld JR, Yurgel SN, Brown JR, Taylor CM, Huttenhower C, Langille MGI (2020) PICRUSt2 for prediction of metagenome functions. Nat Biotech 38:685-688. https://doi.org/10.1038/s41587-020-0548-6

43. Anderson MJ (2001) A new method for non-parametric multivariate analysis of variance. Aus Ecol 26:32-46. https://doi.org/10. 1111/j.1442-9993.2001.01070.pp.x

44. Oksanen J, Blanchet FG, Kindt R, Legendre P, Minchin PR, O'Hara RB, Simpson GL, Solymos P, Stevens M, Wagner H (2016) Vegan: Community Ecology Package. R Package version 2.4-1. http://CRAN.R-project.org/package $=$ vegan

45. Parks DH, Tyson GW, Hugenholtz P, Beiko RG (2014) STAMP: Statistical analysis of taxonomic and functional profiles. Bioinformatics 30:3123-3124. https://doi.org/10.1093/bioinformatics/btu494

46. Wierzchos J, Ascaso C (1994) Application of back-scattered electron imaging to the study of the lichen rock interface. J Microsc 175:54-59. https://doi.org/10.1111/j.1365-2818.1994.tb04787.x

47. Jürgens N, Oldeland J, Hachfeld B, Erb E, Schuitz C (2012) Ecology and spatial patterns of large-scale vegetation units within the central Namib Desert. J Arid Environ 93:59-79. https://doi.org/ 10.1016/j.jaridenv.2012.09.009

48. Jung P, Baumann K, Lehnert LW, Somolov E, Achilles S, Schermer M, Wraase LM, Eckhardt K, Bader MY, Leinweber P, Karsten U, Bendix J, Büdel B (2019) Desert breath-How fog promotes a novel type of soil biocenosis, forming the coastal Atacama Desert's living skin. Geobiol 18.https://doi.org/10.1111/gbi.12368

49. Warren-Rhodes KA, McKay CP, Boyle LN, Wing MR, Kiekebusch EM, Cowan DA, Stomeo F, Pointing SB, Kaseke KF, Ecdardt F, Herschel JR, Anisfeld A, Seely M, Rhodes KL (2013) Physical ecology of hypolithic communities in the central Namib Desert: the role of fog, rain, rock habitat and light. J Geophys Res Biogeosci 118:1451-1460. https://doi.org/10.1002/jgrg.20117

50. Pointing SB (2016) Hypolithic Communities In: Weber B, Büdel B, Belnap J, eds. Biological soil crusts: an organizing principle in drylands. Cham, pp 199-213. https://doi.org/10.1007/ 978-3-319-30214-0

51. Bates ST, Cropsey GWG, Caporaso JG, Knight R, Fierer N (2011) Bacterial communities associated with the lichen symbiosis. Appl Environ Microbiol 77:1309-1314. https://doi.org/10.1128/AEM. 02257-10

52. West NJ, Parrot D, Fayet C, Grube M, Tomasi S, Suzuki MT (2018) Marine cyanolichens from different littoral zones are associated with distinct bacterial communities. PeerJ 6:e5208. https:// doi.org/10.7717/peerj.5208

53. Fierer N, Bradford MA, Jackson RB (2007) Toward an ecological classification of soil bacteria. Ecology 88:1354-1364. https://doi. org/10.1890/05-1839

54. Cardinale M, Puglia AM, Grube M (2006) Molecular analysis of lichen-associated bacterial communities. FEMS Microbiol Ecol 57:484-495. https://doi.org/10.1111/j.1574-6941.2006.00133.x 